\title{
Nonpartisanship of Agents of Parliament: Bill C-520's Redundant and Likely Unconstitutional Approach
}

\author{
Tolga R. Yalkin \& Patrick F. Baud ${ }^{\star}$
}

\section{Introduction}

Bill C-520 - the Supporting Non-Partisan Offices of Agents of Parliament Act - has garnered a degree of interest among parliamentarians and the media uncharacteristic of most private member's bills. ${ }^{1}$ Some MPs have described the bill as a necessary measure to ensure the "neutrality and independence" of the officers of agents of Parliament, while others question its necessity given existing protections and the fact that there "have never been any proven incidents of partisan activities or apparent conflicts in those offices." ${ }^{2}$ The bill's most controversial provisions - including the creation of a vague mechanism for parliamentarians to request that agents of Parliament investigate their own staff for behaving in a partisan manner - were removed when the bill was before committee in the House of Commons. $^{3}$

The bill's remaining provisions do three things. First, they require all employees of agents of Parliament to declare any politically partisan positions they held in the past ten years. ${ }^{4} \mathrm{Sec}$ ond, they require all employees to enter into an undertaking to "conduct themselves in a nonpartisan manner ... in fulfilling the official duties and responsibilities of the position." 5 Third, they require all employees to declare their intent to hold any politically partisan positions while in office. ${ }^{6}$ All declarations are to be posted on the agent of Parliament's website. ${ }^{7}$
This paper argues that these provisions are redundant given the existing restrictions on the political activities of employees and that the bill fails to respect employees' Charter rights. Part I examines the manner in which the existing restrictions on political activities in the federal public service apply to the employees of agents of Parliament. Part II evaluates the additional restrictions that Bill C-520 would place on their employees' ability to hold politically partisan positions. Part III considers the constitutionality of the proposed restrictions, finding that they raise significant concerns regarding the fundamental freedoms and rights guaranteed by the Charter. The restrictions would not likely be saved under section 1 as they do not seem rationally connected to the purpose of the bill nor minimally impair the rights of those they affect, and their deleterious effects seem to outweigh their salutary effects.

\section{Existing restrictions on political activities}

Employees of agents of Parliament are, for the most part, treated like ordinary public servants. ${ }^{8}$ Accordingly, they are already subject to restrictions on their political activities by virtue of Part 7 of the Public Service Employment Act and the Values and Ethics Code for the Public Sector. The Public Service Employment Act prohibits public 
servants from engaging in political activity that would impair or appear to impair their impartiality; the Values and Ethics Code for the Public Sector prohibits employees from acting in a partisan manner.

\section{A. Public Service Employment Act}

The Public Service Employment Act forbids public servants from engaging in political activities that "impair" or are "perceived as impairing the employee's ability to perform his or her duties in a politically impartial manner." The Act defines "political activity" as 1) "carrying on any activity in support of, within or in opposition to a political party"; 2) "carrying on any activity in support of or in opposition to a candidate before or during an election period"; or 3) "seeking a nomination as or being a candidate before or during the election period." ${ }^{10}$ This prohibition on political activities is seemingly broader than the definition of "politically partisan positions" which would have to be disclosed under Bill-520. ${ }^{11}$

In addition, before seeking a nomination or becoming a candidate in a federal, provincial, or municipal election, employees must seek permission from the Public Service Commission and are subject to any conditions the Commission imposes. ${ }^{12}$ The Commission may grant permission "only if it is satisfied that being a candidate during the election period will not impair or be perceived as impairing the employee's ability to perform his or her duties in a politically impartial manner" based "on factors such as the nature of the election, the nature of the employee's duties, and the level and visibility of the employee's position." 13

The Commission can investigate allegations that employees have engaged in political activities in a manner that impairs or is perceived to impair their ability to perform their duties in a politically impartial fashion or that they failed to seek permission to run for a nomination or in an election. ${ }^{14}$ If the allegation proves true, then the Commission may "dismiss the employee or take any corrective action that it considers appropriate." ${ }^{15}$
The restrictions on political activities in the Public Service Employment Act have not been the subject of a reported constitutional challenge since they came into force in 2005. The more onerous restrictions in the previous version of the Public Service Employment Act, were struck down by the Supreme Court of Canada in Osborne v Canada (Treasury Board). ${ }^{16}$

\section{B. The Values and Ethics Code for the Public Sector}

The Values and Ethics Code for the Public Sector is a condition of employment for every civil servant in the federal public sector, including employees of agents of Parliament; serious breaches may be investigated under the Public Servants Disclosure Protection Act. ${ }^{17}$ The Code clearly prohibits public servants, including agents of Parliament, from engaging in partisan behavior. The Code describes the role of a "professional and non-partisan federal public sector [as] integral to [Canadian] democracy." ${ }^{18}$ The Code sets out five values intended to "guide public services in everything they do," including respect for democracy, for which a "non-partisan public sector is essential," and integrity, which "conserve[s] and enhance[s] public confidence in the honesty, fairness and impartiality of the federal public sector." ${ }^{19}$ This emphasis on non-partisanship is further highlighted in the expected behaviours related to these values. ${ }^{20}$

Public servants may be subject to disciplinary measures, including termination of employment, if their conduct contradicts these values and expected behaviours. ${ }^{21}$ If such activities were to take place on a sufficient scale as to constitute a serious breach of the Code, this would constitute wrongdoing under the Public Servants Disclosure Protection Act and possibly trigger an investigation by the Public Sector Integrity Commissioner. ${ }^{22}$

\section{Proposed restrictions on partisan activities}

Bill C-520's stated purpose is "to avoid conflicts that are likely to arise or be perceived to arise between partisan activities and the official duties 
and responsibilities of an agent of Parliament or any person who works in the office of an agent of Parliament." ${ }^{23}$ During the second reading debate, Mark Adler, the Conservative MP who introduced the bill, clarified his view of its purpose. Adler argued that the purpose of the bill is to hold agents of Parliament and their employees to a higher standard than ordinary public servants when it comes to their political activities, due to their "vital role in government oversight," "close relationship with parliamentarians," and "high level of political visibility." Adler suggested that "former partisans" could undermine the "neutrality and independence" of agents' work on behalf of Parliament. ${ }^{24}$

The bill applies to nine existing agents of Parliament: the Auditor General, the Chief Electoral Officer, the Commissioner of Official Languages, the Privacy Commissioner, the Information Commissioner, the Senate Ethics Officer, the Conflict of Interest and Ethics Commissioner, the Commissioner of Lobbying, and the Public Sector Integrity Commissioner. ${ }^{25}$ The bill also allows the Governor in Council to designate "any other position" as an agent of Parliament for the purposes of the bill, which would make it possible to extend the bill to others, such as the Library of Parliament, Office of the Parliamentary Budget Officer, or the Canadian Human Rights Commission. ${ }^{26}$

\section{A) Declaration of past activities}

The bill would also require "[e]very applicant for a position in the office of an agent of Parliament" to provide a "written declaration stating whether or not, at any time, in the 10 years prior to applying for the position, they occupied a politically partisan position," as described above. ${ }^{27}$ The declaration "must indicate the nature of any such position, as well as the period of time during which the person occupied it." ${ }^{28}$ If the applicant is hired, the declaration must be made publicly available online within a month. ${ }^{29}$ The requirement also applies to current employees, who must post such a declaration online within 30 days of the legislation coming into force..$^{30}$ Although they are likely a small minority, there are probably many individuals who work for agents of Parliament who, in the last 10 years, occupied these positions.

The relationship between this requirement and the bill's broader purpose is unclear. Perhaps the intent is to discourage applicants with partisan experience from applying to work for an agent. Alternatively, the intent could also be to discourage agents from hiring employees with partisan experience for fear of having the employees' past damage the agent's reputation and, by extension, undermine the credibility of their work. However, in his testimony on the bill, Auditor General Michael Ferguson suggested that the officers would be unable to take past partisan positions into account without falling afoul of the requirements in the Public Service Employment Act that they hire on the basis of merit. ${ }^{31}$ The Act defines merit in terms of meeting essential qualifications and selection based on asset qualifications, operational requirements, and organizational needs. What constitutes an essential or asset qualification must have some substantive content. Something cannot be essential unless it is necessary for the employee to perform the job, whereas an asset qualification must improve job performance.

Qualifications must respect the Charter. Including the absence of political affiliation as a qualification would likely raise issues around discrimination and freedom of association under the Charter. Such a qualification would have to be justifiable under section 1 of the Charter. For a few positions, such as elections returning officers, the absence of any history of partisan employment would likely survive Charter scrutiny. However, for most employees of agents of Parliament, such history is likely irrelevant, if not beneficial. Partisan employment may develop relevant skills, and an awareness of the political environment can be helpful in assisting agents of Parliament and their staff. ${ }^{32}$ The explicit statement that appointments must be "free from political influence" already adequately addresses the need to avoid injecting politics into staffing decisions.

The disclosure requirement may undermine the contribution of agents of Parliament and their staff by creating a chilling effect on their activi- 
ties. Agents were generally established to assist parliamentarians in carrying out their constitutional duties, including deliberating government policies, holding the government to account for its activities, and authorizing the raising and spending of public monies. ${ }^{33}$ Doing so frequently involves pointing out problems with government policy and suggesting opportunities to address them. Some parliamentarians may seize upon the past activities of the employees of agents of Parliament to question the legitimacy of the agent's work by casting aspersions over underlying motivations, which could in turn distract the agent from fulfilling their mandate.

\section{B) Written undertaking}

The bill also requires that every applicant for a position in the office of an agent of Parliament and every employee "provide a written undertaking indicating that they will, in fulfilling the official duties and responsibilities of [their] position ... conduct themselves in a non-partisan manner." ${ }^{34}$ The bill does not provide a definition for the term "non-partisan manner" and Adler did not provide any clarification when asked during his committee testimony on the bill. ${ }^{35}$ That said, this requirement seems redundant as employees are already required to conduct themselves in an impartial and nonpartisan manner under the Values and Ethics Code for the Public Sector. ${ }^{36}$

\section{C) Declaration of future intent}

The bill would require agents of Parliament and their employees to publicly disclose their intention "to occupy a politically partisan position" and to specify the "nature of the position, as well as the period of time during which the [the employee of or agent of Parliament] intends to occupy it." ${ }^{37}$ The bill defines a "politically partisan position" as 1) an "electoral candidate" in a federal election; 2) a federal "electoral district association officer"; 3) a "member of ministerial staff"; 4) a "member of a parliamentary staff"; and 5) a "member of political staff." 38

Most employees of agents of Parliament certainly any with significant discretion to direct the work of the agent's office - would not likely be able to work as a member of ministerial, par- liamentary, or political staff, even on a contractual or part-time basis, while remaining in their position in the agent's office. Doing so would almost certainly violate the requirements of impartiality and nonpartisanship specified in the Values and Ethics Code for the Public Sector and, by extension, the terms of their employment. ${ }^{39}$ Such work would also likely constitute political activity that would "impair or be perceived as impairing the employee's ability to perform his or her duties in a politically impartial manner" contrary to the Public Sector Employment Act. Either way, the employee would be subject to disciplinary action, including potential dismissal.

Although it would be possible for an agent's employee to occupy a politically partisan position by virtue of being a candidate in a federal election, he or she would not be able to do so unless granted permission and a leave of absence by the Public Service Commission. ${ }^{40}$ The Commission may only grant permission "if it is satisfied that the employee's ability to perform his or her duties in a politically impartial manner will not be impaired or perceived to be impaired." ${ }^{1}$ In evaluating the degree of actual or perceived impairment, the Commission "may take into consideration factors such as the nature of the election, the nature of the employee's duties and the level and visibility of the employee's position." ${ }^{42}$

Considering the role played by agents of Parliament and by extension, the nature of the duties of their employees, it seems likely that the Commission would be more reluctant to grant permission to agents' employees to run in federal elections than they would be for other parts of the public service. Even if the Commission were to grant an agent's employee permission to run in an election, which it has done on three occasions since 2008, the Commission would be required to disclose that it has done so in the Canada Gazette. ${ }^{43}$

Although an employee may consider running without receiving the Commission in the $\mathrm{n}$ federal elections thay that they can be said to truly intend to run until they receive permission. If this is true, an employee would consider running, request permission from the Commission, 
who would gazette its decision, and the employee would have to publicly declare his or her intention to run. Thus, the bill at best provides a second forum for disclosing that an employee is running as a candidate. The disclosure of future intent to engage in partisan activities could be intended to avoid conflicts of interest by discouraging partisan involvement. However, this deterrent effect would not serve the legislation's objective as it would add to the existing restrictions on political activities only when there is no real or apparent conflict of interest.

\section{Constitutional analysis of proposed restrictions}

The public declarations compelled by sections $7(1), 11$, and $7(2)$ in Bill C-520 raise concerns over freedom of expression, equality rights, and freedom of association which are protected in the Canadian Charter of Rights and Freedoms. ${ }^{44}$

\section{A) Freedom of expression}

Freedom of expression includes freedom from being forced to express. ${ }^{45}$ In Slaight Communications $v$ Davidson, a labour adjudicator exercising authority under the Canada Labour Code required an ex-employer to respond to any requests for a reference on behalf of the employee with a letter certifying the employee's employment and confirming his sales quota performance, stating only that he had been unjustly dismissed. Justice Lamer, whom the majority endorsed on this point, ${ }^{46}$ held that section 2 (b) was engaged:

There is no doubt in the case at bar that the part of the order dealing with the issuing of a letter of recommendation places, in my opinion, a limitation on freedom of expression. There is no denying that freedom of expression necessarily entails the right to say nothing or the right not to say certain things. Silence is in itself a form of expression which in some circumstances can express something more clearly than words could do. The order directing appellant to give respondent a letter containing certain objective facts in my opinion unquestionably limits appellant's freedom of expression. ${ }^{47}$
Under Bill C-520, prospective and current employees would be required to publicly disclose their employment in politically partisan positions for the last 10 years. While these declarations are certainly expressive activity, the Crown may argue in defence of the bill that the declaration compelled is one of true fact, that the information would be disclosed in any event, or that the individual is free to contradict the information. ${ }^{48}$

It is irrelevant that the declaration compelled is one of true fact. In Slaight, the letter the company was bound to provide did not express any opinions, but simply stated facts regarding duration of employment and sales numbers. ${ }^{49}$

It is likewise irrelevant that employment history would, in the ordinary course of things, be provided to the agent of Parliament. While applicants provide details of previous employment when applying for a position and when seeking security clearance, the bill would require the public declaration of this information. Furthermore, by singling out politically partisan positions, the bill gives these facts a new emphasis. In effect, applicants are required to publically declare select information perceived as negatively reflecting upon their ability to behave in a non-partisan manner.

It may be relevant that the individual making the declaration would be free to contradict the meaning conveyed by these declarations. McLachlin CJ's decision in RJR Macdonald and Wilson J's obiter in Lavigne $v$ OPSEU suggest that a requirement to engage in expressive activity combined with a restriction to limit the nature or content of that expressive activity infringes freedom of expression. In RJR Macdonald, McLachlin CJ seemed to view the "combination of the unattributed health warnings and the prohibition against displaying any other information" as infringing freedom of expression. ${ }^{50}$ Similarly, in Lavigne $v$ OPSEU, Wilson J suggested, without expressly concluding, that Slaight turned on the requirement to make some declaration paired with the restriction on saying anything more. ${ }^{51}$

The bill provides that the Governor in Council prescribes the content of the declaration. It 
would seem, therefore, that the information the declarant would be free to provide would be limited in some way, and this would seem to infringe freedom of expression. If the declarant is free to add information as he or she wishes, based on the authorities cited above, it is not as clear that freedom of expression would be engaged.

A finding that the activity in question is within the scope of freedom of expression will satisfy the first requirement for determining an infringement of section 2(b). The next question the court must ask is whether constraining said activity is in fact Parliament's purpose, ${ }^{52}$ in which case section $2(\mathrm{~b})$ is engaged. If its purpose is not to constrain the activity and that doing so is merely a by-product of the bill, the court must interrogate whether the expressive activity that is constrained promotes one of the objectives of freedom of expression, including democracy, the search for truth, and self-fulfillment.

Sections 7 and 11 directly control expression; the provisions require employees to express themselves through a declaration. ${ }^{53}$ This situation is similar to Osborne $v$ Canada, which held that prohibiting public servants from speaking out in favour of a political party or candidate was intended to restrict expressive activity. ${ }^{54}$ The declaration is clearly not an unintended adverse effect but rather the direct purpose of the provision.

\section{B) Equality rights}

The bill distinguishes those who have past political affiliations by requiring them to make a public declaration. The status of political affiliation as an analogous ground remains unsettled. At the trial level, political belief has been upheld as analogous, ${ }^{55}$ but while the decision was affirmed on appeal on other grounds, the appellate court expressed reservations about the trial judge's conclusion on this point. ${ }^{56}$

It would seem, however, that political beliefs or political affiliation should be an analogous ground on the basis of the criteria set out in Corbière. ${ }^{57} \mathrm{~A}$ person's past political affiliations are a fundamental part of their identity. Moreover, political beliefs are widely recognized as a pro- tected ground in provincial human rights statutes and in international law. ${ }^{58}$

If political affiliation is an analogous ground, it would follow that distinguishing people on the basis of whether or not they held politically partisan positions would amount to unequal treatment. The question then becomes whether or not this unequal treatment is discrimination. In that case, the distinction might be argued to perpetuate stereotypes around individuals who are politically affiliated; ${ }^{59}$ it presupposes that individuals who have held a politically partisan position in the last 10 years are less capable of providing non-partisan public service. The bill's sponsor confirms this view:

Would the opposition trust a report issued out of an office staffed by former professional Conservative partisans? I do not believe so and it is understandable that they might not. The same goes for us on this side of the House. We would be suspicious of a report prepared by NDP partisans ... [Bill C-520] respects the process and ensures that these offices are being operated and populated as intended. ${ }^{60}$

However, it is not clear that individuals who have held politically partisan positions are less capable of discharging their roles. Employees may have worked for the party in a non-partisan capacity, for instance, conducting research, or in a capacity in which partisan sentiments are irrelevant, such as in Information Technology (IT) support. Even where neither is the case, they may no longer adhere to that party's positions. Furthermore, even where they might identify with a political stripe, they might still yet be relied upon to carry out their role at an agent of Parliament in a professional and non-partisan fashion. By requiring a public declaration from everyone without considering individual circumstances, it might be argued that the bill perpetuates the stereotype that all former employees of political parties are less capable of acting in a non-partisan manner.

\section{C) Freedom of association}

Employees' freedom of association is already limited, in a justifiable manner, under the Public Service Employment Act. ${ }^{61}$ The requirement that 
employees declare their intent to occupy partisan employment also likely infringes that freedom.

In Dunmore, the court recognized that "the purpose of section 2(d) [freedom of association] commands a single inquiry: has the state precluded activity because of its associational nature, thereby discouraging the collective pursuit of common goals?" 62 Here, an explicit purpose of the legislation is to deter employees of agents of parliament from taking up employment with political parties, ${ }^{63}$ which, in turn, may interfere with the employee's pursuit of political goals. ${ }^{64}$ The PEI Court of Appeal has recognized political association as a form of protected association and the SCC has done so implicitly. ${ }^{65}$ Thus, while speculative, it is possible that the requirement of a declaration breaches freedom of association.

\section{D) Justification under Section 1}

In sum, Bill C-520 may be found to interfere with freedom of expression, equality rights, and freedom of association. Once such a prima facie violation of the Charter is established, the burden of justifying the infringement shifts to the government under section 1 of the Charter, in accordance with the test specified in $R v$ Oakes. ${ }^{66}$

It would seem that the overall purpose of the declarations is to ensure that employees and agents of Parliament discharge and are seen to discharge their official duties in a non-partisan manner. There can be little question that this purpose is sufficiently important to satisfy the first step of the Oakes test.

The bill seeks to achieve the above-mentioned purpose by reducing the "population" of individuals who have held and hold politically partisan positions. ${ }^{67}$ It may be argued that the public declarations will reduce the population in three ways: 1 ) by deterring those who have held politically partisan positions from taking up or continuing employment with agents of Parliament; 2) by deterring agents of Parliament from hiring, promoting, and retaining those same individuals; and 3) by deterring those working for agents of Parliament from taking up politically partisan positions.
Whether or not the means adopted is rationally connected to reducing this population, however, is a matter of debate. The Public Service Employment Act does not currently seem to permit employment decisions to be made on the basis of political affiliation, ${ }^{68}$ a matter Auditor General Michael Ferguson raised at committee. ${ }^{69}$ If agents of Parliament cannot take the political nature of a past position into consideration when hiring, it is not clear that the provision would actually have the deterrent effects mentioned above. If true, then section 7 and 11 would not reduce the population of employees who have held politically partisan positions.

At question is also whether the declarations minimally impair the rights of employees of agents of Parliament. It would seem that the purpose of ensuring that employees and agents of Parliament publicly discharge their official duties in a non-partisan manner could be achieved by less invasive means. Some of these means already exist; as mentioned above, employees and agents of Parliament are already required to conduct themselves in a non-partisan manner. Moreover, even if this were insufficient to achieve the stated purpose of substantially achieving the objective, it does not follow that individual candidates and employees should declare themselves publically. It would seem sufficient, for example, to require agents to disclose aggregate statistics on the number and seniority of employees who have held politically partisan positions or, in some cases, the same characteristics of specific teams producing a particular report. Finally, even if such a mechanism were necessary for some employees, the bill still does not minimally impair rights because it could be better tailored to the circumstances of each organization and role. The SCC relied on this rationale in Osborne v. Canada (Treasury Board), finding that restrictions on political activities of the public service are an unconstitutional infringement of freedom of expression, unjustifiable under section 1 due to overbreadth: "the restrictions apply to a great number of public servants who in modern government are employed in carrying out clerical, technical or industrial duties that are completely divorced from the exercise of any discretion that could be in any manner affected by political considerations." ${ }^{70}$ 
Finally, significant concerns remain around the question of proportionality. While ensuring employees and agents of Parliament discharge and are perceived to discharge their official duties in a non-partisan manner is important, it is unclear how forcing public declarations of individual partisan employment history would significantly reduce the population of people who have worked in past politically partisan positions, or that such a reduction would have a significant impact in terms of the perceived or actual impartiality of agents of Parliament. As mentioned above, an array of mechanisms already ensure that these individuals behave in a non-partisan manner. In addition, there is little publicly available evidence of any behaviour to the contrary. That said, the declarations would significantly impact declarants' freedom of expression, equality rights, and, in the case of the declaration of intent, freedom of association. While the transparency provided by the bill may improve perceptions of non-partisanship, it may also have a deleterious effect of undermining agents of Parliament and their offices by creating a perception of conflicts of interest where none actually exist.

\section{Conclusion}

Partisan activities by employees of agents of Parliament are already well regulated: the Public Service Employment Act prohibits public servants from engaging in political activity that would impair or appear to impair their impartiality and the Values and Ethics Code for the Public Sector prohibits employees from acting in a partisan manner. Bill C-520 appears to have been drafted without a sufficient awareness of this existing regime. The bill requires public servants to disclose partisan history even though such history cannot be taken into account in their hiring or retention; to disclose any intentions to engage in partisan activities even though such activities are already prohibited if they would impair their real or apparent impartiality; and to solemnly affirm a narrow version of the Values and Ethics Code for the Public Sector they already sign when accepting employment.
The restrictions the Public Service Employment Act places on political activities were tailored to reflect the decision of the SCC in Osborne, which recognized the political rights and freedoms of employees as well as their individual circumstances. Bill C-520 runs roughshod over employees' rights and freedoms by attempting to compel expression, encourage discrimination in hiring, and discourage political association. These restrictions would not likely be saved under section 1 as they do not seem rationally connected to the purpose of the bill; they seem not to minimally impair the rights of those they affect; and their deleterious effects seem to outweigh their salutary effects.

In conclusion, significant portions of the bill are duplicative of existing regulation, introduce ambiguity into the regime for the regulation of public servants, and are of dubious constitutionality.

\section{Notes}

* Tolga R Yalkin is Professor of Law at the University of Ottawa. Patrick F Baud is an MA student in Political Studies at Queen's University. He will be starting the BCL/LLB program at McGill University in Fall 2014.

1 Bill C-520, An Act supporting non-partisan agents of Parliament, 1st Sess, 41st Parl, 2013 (second reading 12 February 2014) [Bill C-520].

2 House of Commons Debates, 41st Parl, 2nd Sess, No 20 (20 November 2013) at 1134-1135, 1137, 1139 [Debates].

3 House of Commons, Standing Committee on Access to Information, Privacy and Ethics, Minutes of Proceedings (15 May 2014) (Chair: Pat Martin).

4 Bill C-520, supra note 1 at $\mathrm{cl} 7(1)$.

5 Ibid at cls 8, 13.

6 Ibid at cls 7(2), 11.

7 Ibid at cl 11.

8 All employees appointed in accordance with the Public Service Employment Act are subject to the restrictions on political affiliation, according to the Public Service Employment Act, SC 2003, c 22, s 2(1) [PSEA]. With two exceptions, each officer of Parliament's statute indicates that their employees are appointed in accordance with that Act. See Auditor General Act, RSC 1985, c A-17, s 
15(1); Canada Elections Act, SC 2000, c 9, s 19(1); Official Languages Act, RSC 1985, c 31 (4th Supp) s 51; Privacy Act, RSC 1985, c P-21, 58(1); Access to Information Act, RSC 1985, c A-1, s 58(1); Lobbying Act, RSC 1985, c 44 (4th Supp) s 4.3(1); Public Servants Disclosure Protection Act, SC 2005, c 46, s 39.3(1) [PSDPA]. Employees of the Senate Ethics Officer and the Conflict of Interest and Ethics Commissioner are not subject to these restrictions, though they are subject to analogous restrictions and disciplinary mechanisms by virtue of being Parliamentary employees.

9 PSEA, supra note 8 at s 113(1).

10 Ibid at s 111(1).

11 Bill C-520, supra note 1 at cl 2(1).

12 PSEA, supra note 8 at ss 114-115; Political Activities Regulations, SOR/2003-373, ss 2, 4-5 [Political Activities Regulations].

13 PSEA, supra note 8 at ss 114(6), 115(3).

14 Ibid at s 118. See also Political Activities Regulations, supra note 13 at ss 7-14.

15 PSEA, supra note 8 at s 118.

16 Osborne v Canada (Treasury Board), [1991] 2 SCR 69, [1991] SCJ No 45 [Osborne].

17 Canada, Treasury Board of Canada Secretariat, Values and Ethics Code for the Public Sector, (Ottawa: Treasury Board of Canada Secretariat, 2012) at 6 [Values and Ethics Code for the Public Sector]. For applicability of the code, see PSPDA, supra note 8 at s 5(1), 2(1).

18 Ibid at 2 [emphasis added].

$19 \mathrm{Ibid}$ at 3-4 [emphasis added].

20 Ibid at 4-5.

21 Ibid.

22 PSPDA, supra note 8 at ss 8 (a),(e), 22, 24, 38.

23 Bill C-520, supra note 1 at $\mathrm{cl} 3$.

24 Debates, supra note 2 at 1133-1135.

25 Bill C-520, supra note 1 at cl 2(1).

26 Ibid at cl 5(a); Canadian Human Rights Act, RSC 1985, c H-6, ss 26-27; Parliament of Canada Act, RSC 1985, c P-1, ss 75, 79.1-79.2.

27 Bill C-520, supra note1 at cl 7(1).

28 Ibid.

29 Ibid at $\mathrm{cl} 7(3)$.

30 Ibid at cls 11-12.

31 House of Commons, Standing Committee on Access to Information, Privacy and Ethics, "Evidence" in House of Commons Debates, No 13 (25 February 2014) at 11 ["Evidence"]

32 For example, the UK Committee on Standards in Public Life reported that " $\mathrm{t}]$ he restrictions governing who can be an employee of the [Electoral] Commission or become an electoral commissioner has, in our view, led to a shortfall in experience and knowledge of the contemporary political process in the Commission." See UK, Committee on Standards in Public Life, Review of The Electoral Commission (11th report of the Committee of Standards in Public Life) (Norwich, United Kingdom: Her Majesty's Stationery Office, 2007) at 5, online: Committee on Standards in Public Life <http://www.public-standards.gov. uk/wp-content/uploads/2012/11/11thReport_ FullReport.pdf $>$.

33 Audrey O'Briend \& Marc Bosc, eds, House of Commons Procedure and Practice, 2d ed (Ottawa: House of Commons, 2009) at 212.

34 Bill C-520, supra note 1 at $\mathrm{cl} 8$.

35 "Evidence", supra note 31.

36 Values and Ethics Code for the Public Sector, supra note 17 at 6.

37 Bill C-520, supra note 1 at cls 4, 6-7 [emphasis added].

38 Ibid at $\mathrm{cl} 2(1)$.

39 Values and Ethics Code for the Public Sector, supra note 17 at 4 .

40 PSEA, supra note 8 at s 114(1).

41 Ibid at $s$ 114(4).

42 Ibid at s 114(6).

43 Notice (Public Service Commission), (2014) C Gaz I, 1118 (PSEA); Notice (Public Service Commission), (2013) C Gaz I, 525 (PSEA); Notice (Public Service Commission), (2009) C Gaz I, 1829 (PSEA).

44 Bill C-520, supra note 1 at cl 7. Canadian Charter of Rights and Freedoms, Part I of the Constitution Act, 1982, being Schedule B to the Canada Act 1982 (UK), 1982, c 11

45 Slaight Communications v Davidson, [1989] 1 SCR 1038, 59 DLR (4th) 416 [Slaight cited to SCR].

46 Ibid at 1048, Dickson CJC. See also ibid at 1062, Beetz J (Beetz found an infringement of s 2(b) only because the employee was being forced to write, as if they were his own, statements of facts which they might believe to be inaccurate, misleading, or false; consequently, he held that the order would not infringe freedom of expression if it merely required the employer to list the fact as facts found by the adjudicator.)

47 Ibid at 1079 [emphasis added].

48 Irwin Toy Ltd v Quebec (Attorney General), [1989] 1 SCR 967 at 967-969, 58 DLR (4th) 577 [Irwin Toy cited to SCR].

49 Slaight, supra note 46 at 1055.

50 RJR-MacDonald Inc $v$ Canada (Attorney General), [1995] 3 SCR 199 at para 124, 127 DLR (4th) 1.

51 Lavigne v Ontario Public Service Employees Union, [1991] 2 SCR 211 at 270, 278, 81 DLR (4th) 545. 
52 Irwin Toy, supra note 49 at 977.

53 This analysis is consistent with other cases of directly compelled expression in which the issue of purpose was not a live issue.

54 Osborne, supra note 16 at 93.

55 Condon $v$ Prince Edward Island, 2002 PESCTD 41 at para 82, 214 Nfld \& PEIR 244 ("Political belief is a human right, a very personal characteristic, one of fundamental personal importance to the person in a democratic society. It is synonymous with, and feeds, expressly stated Charter protected values. It is changeable, if at all, only at great personal cost and qualifies as being constructively immutable. [...] Persons who hold political belief different than those of the discriminator who exercises political power are highly vulnerable and are relatively disadvantaged. The individual right to freely hold and exercise political belief falls squarely within the statement of the majority judgement in Corbiere, supra at para. 79 as being something that government has no legitimate interest in expecting persons to change to receive equal treatment under the law."), aff'd on other grounds 2006 PESCAD 1, (253 Nfld \& PEIR 265, leave to appeal to SCC refused, 31416 (August 17, 2006) [Condon (PESCTD)]

56 Govt PEI v Condon et al, 2006 PESCAD 1, 253 Nfld \& PEIR 265 at para 43leave to appeal to SCC refused, 31416 (August 17, 2006) [Condon (PESCAD)].

57 Corbiere $v$ Canada (Minister of Indian and Northern Affairs), [1999] 2 SCR 203 at paras 7-13, 60, 173 DLR (4th) 1 [Corbiere] (The criteria used to identify an analogous ground are whether the characteristic is one which is immutable, or immutable changeable only at an a unacceptable cost to personal identity, is used as the bases for decisions based on stereotype rather than merit, and is something in which the government has no legitimate interest in asking us to change. L'Heureux-Dubé, concurring, agreed with these factors and suggested that recognition in human rights legislation is also a significant factor).

58 See Condon (PESCTD), supra note 56 at para 82.

59 See $R v$ Kapp, 2008 SCC 41, [2008] 2 SCR 483 at para 18 (" $[\mathrm{u}]$ nder s. 15(1), the focus is on preventing governments from making distinctions based on the enumerated or analogous grounds that: have the effect of perpetuating group disadvantage and prejudice; or impose disadvantage on the basis of stereotyping.")

60 Debates, supra note 2 at 18:25 -18:30, online: House of Commons <http://www.parl.gc.ca/ HousePublications/Publication.aspx?Pub=Hansar $\mathrm{d} \&$ Doc $=20 \&$ Parl $=41 \&$ Ses $=2 \&$ Language $=\mathrm{E} \& \operatorname{Mod}$ $\mathrm{e}=1 \#$ int $-8143593>$.

61 PSEA, supra note 8 at s 113(1), 117 (section113(1) forbids public service employees from engaging in political activities that "impair" or are "perceived as impairing the employee's ability to perform his or her duties in a politically impartial manner" while s 117 prohibits deputy heads from engaging in any political activity other than voting). See also Osborne, supra note 16 at 93 (stating in obiter without deciding the issue that "it would appear that there is an infringement of s. 2(d) independently of the violation of s. 2(b)").

62 Dunmore v Ontario (Attorney General), 2001 SCC 94, [2001] 3 SCR 1016 at para 16.

63 Debates, supra note 2 at 18:30-18:35 ("Our government fully supports the bill's intent to augment and supplement the existing regime in ensuring that agents of Parliament and their employees do not engage in political activities that conflict or are seen to conflict with their official duties and conduct.")

64 This line of reasoning was accepted in relation to a restriction on remedies for discrimination on the basis of political belief under a provincial human rights act by the PEI Court of Appeal in Condon (PESCAD), supra note 57 at para 33.

65 Condon (PESCTD), supra note 56 at para 33. See also Reference Re Public Service Employee Relations Act (Alta), [1987] 1 SCR 313 at para 154, 78 AR 1 ("[o] ur society supports a multiplicity of organized groups, clubs and associations which further many different objectives, religious, political, educational, scientific, recreational, and charitable. [...] Of particular importance is the indispensable role played by freedom of association in the functioning of democracy." [emphasis added]).

$66 R v$ Oakes, [1986] 1 SCR 103 at para 66, 26 DLR (4th) 200.

67 Debates, supra note 2 at 18:25 -18:30(“[b] ill C-520 respects the process and ensures that these offices are being operated and populated as intended"), online: House of Commons <http://www.parl. gc.ca/HousePublications/Publication.aspx?Pub= Hansard $\&$ Doc $=20 \&$ Parl $=41 \&$ Ses $=2 \&$ Language $=E$ \&Mode $=1 \#$ int $-8143593>$.

68 PSEA, supra note 8 at s 30 ("[a]ppointments by the Commission to or from within the public service shall be made on the basis of merit and must be free from political influence.")

69 House of Commons, Standing Committee on Access to Information, Privacy and Ethics, 41st Parliament, 2nd Sess, No 13 (25 February 2014) at 12:05 -12:10, online: House of Commons <http:// 
openparliament.ca/committees/ethics/41-2/13/ michael-ferguson-1/> (" $[\mathrm{u}]$ nder the current legislation, I appoint employees to my office in accordance with the Public Service Employment Act, PSEA. Employees are hired based on the merit principle. Subclause $7(1)$ of the bill requires an applicant for employment to provide, as soon as possible in the hiring process, a declaration as to whether or not they have occupied a politically partisan position in the past 10 years. Consideration of prior politically partisan positions would not be permitted to influence the current selection process.")

70 Osborne, supra note 16 at 99. 
